\title{
Meningkatkan Hasil Belajar Siswa pada Materi Rangkaian Listrik melalui Model Pembelajaran STAD
}

\author{
Dahniar A \\ SMP Negeri 14 Takengon, Aceh \\ Email: dahniarspd38@gmail.com
}

\begin{abstract}
Abstrak
Penelitian ini bertujuan untuk mendeskripsikan proses peningkatan pembelajaran memahami materi rangkaian listrik melalui model pembelajaran kooperatif tipe STAD pada siswa kelas IX SMP Negeri 14 Takengon. Penelitian ini merupakan penelitian tindakan kelas. Subjek penelitian ini adalah siswa kelas IX SMP Negeri 14 Takengon tahun pelajaran 2018/2019. Setiap siklus dilakukan melalui empat tahapan, yaitu perencanaan, tindakan, observasi, dan refleksi. Data penelitian diperoleh dalam bentuk data kualitatif dan kuantitatif. Data kualitatif dikumpulkan melalui observasi dan catatan lapangan. Selanjutnya, data kuantitatif diperoleh melalui tes unjuk kerja dan angket respon siswa terhadap pembelajaran. Berdasarkan hasil penelitian, penggunaan model pembelajaran kooperatif tipe STAD dalam pembelajaran memahami rangkaian listrik dapat meningkat.
\end{abstract}

Kata kunci: hasil belajar, rangkaian listrik, model pembelajaran STAD

\section{Improving Student Learning Outcomes on Electrical Network Material through The STAD Learning Model}

\author{
Dahniar A \\ SMP Negeri 14 Takengon, Aceh \\ Email: dahniarspd38@gmail.com
}

\begin{abstract}
This study aims to describe the process of improving learning to understand electrical network material through the STAD learning model in class IX students of SMP Negeri 14 Takengon. This research is a classroom action research. The subjects of this study were grade IX students of SMP Negeri 14 Takengon in the 2018/2019 school year. Each cycle is carried out through four stages, namely planning, action, observation, and reflection. The research data were obtained in the form of qualitative and quantitative data. Qualitative data is collected through observation and field notes. Furthermore, quantitative data were obtained through performance tests and questionnaires for students' responses to learning. Based on research results, the use of STAD type cooperative learning models in learning to understand electrical network can increase.
\end{abstract}

Keywords: learning outcome, electrical network, STAD learning model 


\section{PENDAHULUAN}

Pendidikan merupakan salah satu instrumen yang dapat digunakan untuk menumbuhkan saling pemahaman budaya antarwarga dalam beragam kultur. Broom dalam (Suryaman, 2007) mengemukakan bahwa fungsi pendidikan adalah 1) melakukan transmisi budaya, 2) meningkatkan integrasi sosial kemasyarakatan, dan 3) mengembangkan kepriadian. Proses pembelajaran seperti yang diisyaratkan dalam K13 adalah pembelajaran yang berorientasi kepada siswa. Siswa berperan aktif dalam proses belajar mengajar. Dalam hal ini, guru harus mampu menjadi fasilitator dalam pembelajaran. Guru tidak hanya mengajarkan materi kepada siswa, melainkan guru bertugas sebagai pengarah dan pengamat pembelajaran. Guru harus mampu mengondisikan pembelajaran yang inovatif dan bermakna untuk siswa sehingga pembelajaran berlangsung maksimal. Berdasarkan UU RI No. 14 tahun 2005 tentang Guru dan Dosen pasal 10, menentukan bahwa macam-macam kompetensi guru meliputi kompetensi pedagogik, kompetensi kepribadian, kompetensi profesional dan kompetensi sosial. Untuk memiliki keempat kompetensi tersebut, guru harus menjadi pendidik yang professional. Peranan guru lebih banyak menetapkan diri sebagai pembimbing atau pemimpin belajar dan fasilitator belajar. Proses pembelajaran harus dipandang sebagai stimulus yang dapat menantang siswa untuk melakukan kegiatan belajar (A. Syahrin, 2017).

Pada hakikatnya, pembelajaran bertujuan untuk mengantarkan siswa menguasai materi pembelajaran. Siswa diharapkan mampu menguasai setiap pembelajaran dan mencapai kriteria ketuntasan minimal sehingga siswa memperoleh hasil belajar yang baik. Penguasaan materi pembelajaran tersebut akan tercapai dengan baik jika pembelajaran berjalan dengan maksimal.

Problematika dalam pembelajaran IPA khusus materi rangkaian listrik siswa merasa kesulitan memahami jenis materi tertentu yang menyebabkan dalam pembelajaran kurang tercapai suatu kompetensi dasar yang seharusnya merupakan satu tujuan yang diinginkan oleh setiap pendidik. Bila pembelajaran Ilmu Pengetahuan Alam (IPA) hanya didominasi dengan metode ceramah maka mata pelajaran IPA dapat menjadi mata pelajaran yang membosankan bagi siswa, karena mereka tidak secara 
langsung mengetahui dari apa yang didengarnya, yang menyebabkan antara siswa dan pendidik tidak terjadi intraksi yang aktif, bertukar informasi, berbicara dan mengemukakan pendapat.

Rendahnya minat belajar siswa dapat diketahui pada saat pembelajaran berlangsung dengan cara mengamati bagaimana aktivitas siswa saat mengikuti pembelajaran, intraksi antara guru dan siswa, intraksi antarsiswa, dan motivasi belajar siswa. Hal itu menunjukkan minat belajar siswa masih rendah dan perlu ditingkatkan lagi. Peningkatan dilakukan dengan mengubah strategi dan menerapkan metode mengajar yang lebih berkembang atau memperbaharui metode mengajar yang lama menjadi inovatif. Metode mengajar yang inovatif berawal dari pemahaman guru bagaimana mengatur dan menyesuaikannya dengan kondisi kelas.

Materi Pembelajaran rangkaian listrik tidak selalu dapat kita pelajari secara langsung, apabila jika kita ingat bahwa sebagian dari proses materi pembelajaran rangkaian listrik tidak selamanya dilakukan di dalam kelas. Hal-hal yang tidak dapat diamati dan dipelajari sesuai dengan keadaan aslinya sehingga memerlukan alat atau perantara sebagai media. Kelas dapat dijadikan sumber pembelajaran sangat bergantung kepada guru dalam melaksanakan perannya sebagai pengelola kelas. Pembelajaran rangkaian listrik dalam proses pembelajaran di kelas perlu ditingkatkan guru. Guru perlu melakukan pembaharuan dalam proses pembelajaran dengan cara mengubah model pembelajaran yang selama ini digunakan dengan model yang lebih menarik bagi siswa. Guru harus menyadari bahwa keberhasilan pembelajaran IPA tidak hanya ditentukan oleh kemampuan guru dalam menyajikan materi saja, tetapi juga ditentukan oleh kemampuan guru membelajarkan siswa sesuai dengan kebutuhan siswa.

Sebagai solusi dari masalah ini, diperlukan model pembelajaran yang dapat memotivasi siswa berkeinginan untuk terus mengembangkan pengetahuan yang dimilikinya. Model pembelajaran yang dimaksud adalah model pembelajaran inovatif yang membuat siswa di kelas menjadi aktif dan kreatif sehingga suasana pembelajaran lebih kondusif. Model yang digunakan sebaiknya memberikan keleluasaan terhadap siswa untuk berlatih dalam belajar. Salah satu model 
yang dapat diterapkan dalam dalam pembelajaran. Dari beberapa pembelajaran IPA, yakni model cakupan materi pembelajaran rangkaian pembelajaran STAD (Student Teams listrik, STAD merupakan salah satu cara Achievement Divisions). Model STAD yang dapat dijadikan alternatif adalah bagian dari pembelajaran model pemecahan masalah. Selain itu, siswa kooperatif. Pembelajaran kooperatif yaitu pembelajaran yang menekankan pada interaksi sosial, keterlibatan intelektual dan tanggung jawab bersama (Robert, 2005). Ada delapan prinsip yang melekat pada pembelajaran kooperatif, yaitu pengelompokan heterogen, keterampilan kolaboratif, otonomi kelompok, interaksi simultan, partisipasi yang setara, tanggung jawab individu, ketergantungan positif, dan kerjasama sebagai nilai (Subiyantoro \& M., 2018).

Shelton \& Rawlings (2012) mendefinisikan bahwa pembelajaran kooeratif adalah metode pembelajaran yang menggunakan interaksi sosial sebagai sarana membangun pengetahuan. Pembelajaran kooperatif muncul dari konsep bahwa siswa akan mudah menemukan dan memahami konsep yang sulit, di mana siswa saling berdiskusi dengan temannya. Alasan inilah menjadi dasar dalam pemilihan model STAD, di mana dalam model STAD siswa dilibatkan secara penuh juga akan merasa nyaman dalam belajar karena diberikan kebebasan berekspresi dalam belajar secara individu maupun kelompok. Walaupun demikian, siswa tetap memperoleh pengarahan dan bimbingan dari guru. Saat proses pembelajaran berlangsung pendidik harus selalu memberikan motivasi dan membimbing peserta didik belajar (Alfi Syahrin, 2015).

Penerapan model pembelajaran dalam pembelajaran rangkaian listrik diharapkan akan dapat meningkatkan minat, motivasi, serta proses pembelajaran siswa yang minim. Diharapkan model tersebut akan dapat meningkatkan hasil pembelajaran rangkaian listrik. Dengan demikian, tuntutan pembelajaran yang diatur dalam standar kompetensi tingkat SMP dan MTSN khususnya kelas IX, akan dapat terpenuhi dan terlaksana dengan baik. Jadi, berdasarkan fenomena serta uraian yang telah dipaparkan tersebut, dapat disimpulkan bahwa penelitian ini penting untuk dilaksanakan. 


\section{METODE}

Jenis penelitian yang akan digunakan dalam penelitian ini adalah Penelitian Tindakan Kelas (PTK). Penelitian tindakan kelas merupakan penelitian yang mengacu kepada tindakan yang dapat dilakukan guru secara langsung, prakstis, dan relevan dengan situasi yang aktual dalam kelas tertentu sehingga dapat dijadikan alternatif untuk usaha memperbaiki proses pembelajaran. Penelitian tindakan kelas bertujuan untuk memecahkan masalah-masalah praktis yang dihadapi oleh guru dalam proses pembelajaran yang dilaksanakan (Wiriaatmadja, 2006).

Asrori (2008) mengemukakan bahwa penelitian tindakan kelas merupakan suatu bentuk penelitian yang bersifat reflektif dengan melakukan tindakan-tindakan tertentu untuk memperbaiki dan meningkatkan praktik pembelajaran di kelas secara lebih berkualitas sehingga siswa dapat memperoleh hasil belajar yang lebih baik. Wiriatmadja (2005:13) menjelaskan bahwa penelitian tindakan kelas adalah usaha guru untuk mengorganisasikan kondisi parktik pembelajaran yang dilakakukan dan belajar dari pengalaman mereka sendiri.
Penelitian tindakan kelas ini memiliki siklus dengan langkah-langkah (1) perencanaan (plan), (2) pelaksanaan (action), (3) pengamatan (observation), dan (4) perenungan (reflection). Siklus penelitian ini dilakukan dengan ketentuan apabila ketuntasan belajar yang diharapkan terpenuhi, penelitian tindakan kelas ini dianggap telah menyelesaikan permasalahan yang dihadapi. Secara jelas, siklus yang terdiri dari empat langkah utama ini akan dijabarkan dalam bentuk siklus penelitian yang akan dilakukan pada peserta didik.

Untuk seorang guru, pengumpulan data dapat dilakukan di kelasnya sendiri. Dalam hal rancangan penelitian deskriptif aplikatif, maka pengumpulan data dapat dilakukan dengan menggunakan dan data yang dikumpulkan misalnya tentang tanggapan siswa atas metode pembelajaran baru yang telah dilakukan guru atau hasil observasi atas sikap siswa pada saat guru menyajikan pembelajaran dengan metode baru. Data lain yang perlu dikumpulkan misalnya adalah nilai hasil belajar siswa, yang diperoleh dari metode dokumentasi, dan keaktifan siswa, yang diperoleh dari hasil pengamatan. 
Ada beberapa cara teknik pengumpulan data yang dapat digunakan dalam sebuah penelitian (Yusuf, 2003). Teknik-teknik pengumpulan data ini didasarkan kepada tiga jenis penelitian, yaitu: 1) pustaka, 2) lapangan, 3) laboratorium. Beberapa di antara teknik pengumpulan data tersebut adalah angket, pedoman wawancara, tes, dan lain-lain. Teknik pengumpulan data pada penelitian ini sebagai berikut.

Data yang dianalisis dalam penelitian ini terdiri dari data kualitatif dan data kuantitatif. Kedua jenis data tersebut dianalisis secara berbeda. Miles and Huberman dalam (Robert, 2005) analisis data kualitatif meliputi reduksi data, penyajian data, dan penarikan kesimpulan/verifikasi. Reduksi data diartikan sebagai proses pemilihan, perumusan perhatian pada penyederhanaan, pengabstrakan, dan transformasi data kasar yang muncul dari catatan lapangan tertulis di lapangan.

Penyajian data merupakan sekumpulan informasi tersusun yang memberi kemungkinan adanya penarikan kesimpulan dan pengambilan tindakan. Penarikan kesimpulan merupakan kegiatan dari konfigurasi yang utuh. Kesimpulan-kesimpulan juga diverifikasi selama penelitian berlangsung, yang mungkin saja masih singkat dan dicatat oleh peneliti atau oleh teman sejawat yang ikut mengamati. Reduksi data, penyajian data, dan penarikan kesimpulan/ verifikasi merupakan sesuatu yang saling terkait pada sebelum, selama, dan sesudah pengumpulan data dalam bentuk yang sejajar.

\section{HASIL DAN PEMBAHASAN}

Penelitian ini dilakukan dua siklus, yaitu siklus I dan siklus II. Sebelum kedua siklus tersebut dilaksanakan, peserta didik masih dikondisikan dalam keadaan biasa. Keadaan biasa adalah keadaaan yang belum mendapat pengaruh atau perlakukan sesuai dengan metode yang digunakan dalam penelitian ini. Artinya, pembelajaran dilaksanakan tanpa penggunaan model yang akan digunakan dalam penelitian ini.

Berdasarkan kondisi awal tersebut, secara umum dapat dinyatakan bahwa peserta didik belum terampil menjelaskan rangkaian listrik sesuai dengan kompetensi yang diharapkan dalam pelajaran IPA. Peserta didik belum mampu menjelaskan rangkaian listrik secara umum dan belum mencapai batas ketuntasan minimal yang telah ditetapkan. 
Pernyataan tentang rendahnya keterampilan menjelaskan siswa mengarah pada fakta pengamatan yang ditemui di lapangan. Hal ini terlihat ketika dilakukan kegiatan diskusi kelompok, hanya 6 dari 20 siswa yang mau menjelaskan tentang rangkaian listrik. Artinya, sebagian besar siswa enggan menjelaskan atau berbicara dan memilih diam. Dengan kata lain, dapat dinyatakan bahwa siswa yang aktif sebelum dilaksanakannya perlakuan terdapat enam siswa. enam siswa ini adalah siswa yang selalu aktif dalam setiap pembelajaran.

Setelah diskusi kelompok selesai, dilaksanakanlah diskusi kelas. Satu kelompok tampil ke depan untuk mempresentasikan hasil diskusi. Di dalam kegiatan ini, siswa yang aktif mengemukakan pendapat berkurang dari pada diskusi kelompok. Hanya 4 siswa yang mau mengemukakan pendapatnya.

Jika dipersentasekan, ada 27,27\% siswa dalam satu kelas yang mampu mengemukakan pendapat dan ada $72,72 \%$ yang tidak mampu mengemukakan dalam diskusi kelompok. Dalam kegiatan diskusi kelas, persentase ini menurun. 9,09\% siswa yang mampu mengemukakan pendapat dan $90,9 \%$ yang tidak mampu mengemukakan pendapatnya dalam diskusi kelas.

Siklus I. Pada kegiatan ini, model pembelajaran disusun dengan memusatkan proses pembelajaran yang berorientasi pada siswa. Pembelajaran dilaksanakan dengan menggunakan model pembelajaran STAD untuk meningkatkan keterampilan berbicara siswa dalam kelas secara kelompok. Pelaksanaan diskusi dengan model pembelajaran STAD dilakukan dalam dua kegiatan, yaitu: diskusi kelompok dan diskusi kelas. Perencanaan yang dilakukan pada siklus I ini dilatarbelakangi oleh persoalanpersoalan yang ditemukan pada prasiklus. Untuk melaksanakan kegiatan tersebut, diperlukan rencana yang matang agar tujuan pembelajaran tercapai dengan maksimal. Rencanarencana yang dilakukan adalah 1) mempersiapkan Buku, gambar, dan peta yang akan didiskusikan siswa, 2) mempersiapkan soal-soal tes untuk mengukur tingkat keterampilan berbicara siswa dalam menjelaskan perjuang para tokoh.

Berdasarkan hasil temuan pada siklus I, terdapat beberapa kelemahan yang terjadi selama pembelajaran berlangsung. Kelemahan tersebut 
terdapat pada kegiatan yang pertanyaan sehubungan dengan materi berhubungan dengan materi dengan model pembelajaran STAD. pembelajaran dan yang tidak Setelah siswa memahami materi berhubungan dengan materi pembelajaran. Kelemahan-kelemahan ini menjadi acuan untuk melakukan perbaikan pada siklus berikutnya. Pemahaman siswa dengan model pembelajaran STAD perlu ditingkatkan. Berdasarkan pengamatan peneliti dan kolaborator, masih ada siswa yang belum memahami model pembelajaran STAD ini. Selain kegiatan yang berhubungan dengan materi pembelajaran, keaktifan siswa juga dipengaruhi oleh kegiatan yang tidak berhubungan dengan materi pembelajaran. Kegiatan yang tidak berhubungan dengan materi pembelajaran berhubungan dengan penempaan mental siswa. Adapun halhal yang dilakukan secara berkesinambungan terhadap siswa adalah memunculkan rasa percaya diri dan meningkatkan kedisiplinan.

Siklus II. Dalam melaksanakan pembelajaran, skenario dikembangkan sebaik mungkin. Skenario dilaksanakan dalam tahapan-tahapan pembelajaran yang sistematis. Tahap pertama adalah perangsangan materi dengan teknik tanya jawab. Guru mengajukan mengemukakan pendapat dengan model pembelajaran STAD, guru menanyakan hal-hal yang mengarah pada permasalahan yang ada dalam teks yang akan dibahas dalam diskusi kelompok. Cara ini bertujuan untuk mengantarkan siswa agar lebih memahami teks yang akan didiskusikan dan siswa mampu mengemukakan pendapatnya tentang permasalahan yang didiskusikan. Setelah dua kegiatan tersebut dilaksanakan, guru beranggapan bahwa siswa sudah cukup menguasai materi pembelajaran.

Berdasarkan hasil pengamatan pada siklus II, dapat disimpulkan bahwa terjadi peningkatan keaktifan siswa sebesar 49,09 \%. Hal yang memungkinkan naiknya keaktifan siswa dalam pembelajaran adalah mereka menyukai pembelajaran dengan model pembelajaran STAD yang bersifat kelompok. Seperti pendapat Sutardji dan Sudirjo (2007) bahwa kegiatan yang berlangsung di lingkungan belajar siswa dalam kelompok kecil yang saling berbagi ide-ide atau bekerja secara kooperatif dapat memecahkan masalahmasalah. Jadi, penggunaan model dalam sebuah pembelajaran sangat membantu 
meningkatkan aktivitas dan keterampilan siswa. Di samping itu, pemilihan bahan pembelajaran ikut menentukan tingkat keaktifan siswa dalam pembelajaran. Jika bahan yang akan mereka kaji dalam pembelajaran dekat dengan kehidupan siswa, mereka bersemangat dalam pembelajaran. Hal ini akan meningkatkan aktivitas siswa dalam pembelajaran. Jika aktivitas siswa telah meningkat, keterampilan siswa dalam sebuah pembelajaran juga akan meningkat.

\section{SIMPULAN DAN SARAN}

Penggunaan model pembelajaran STAD dapat meningkatkan proses keterampilan siswa dalam materi pelajaran rangkaian listrik terutama dalam diskusi. Proses tersebut dapat dilihat dari kelancaran menjelaskan inti dari sebuah topik dalam sebuah teks. Proses keterampilan tersebut dalam penelitian ini meliputi dua aspek, yaitu tingkat keaktifan siswa dan kemampuan mengemukakan pendapat dalam diskusi oleh siswa. Kedua hal tersebut merupakan kunci atau instrumen yang mendasari keberhasilan siswa dalam memahami konsep pembelajaran. Pembelajaran akan menjadi menyenangkan apabila siswa memiliki respons atau pemahaman terhadap materi dan penggunaan model pembelajaran yang relevan.

Pada tingkat keaktifan, terdapat empat kegiatan yang diamati. Kegiatan tersebut adalah perhatian terhadap pembelajaran, keaktifan mengemukakan pendapat, kerjasama dalam kelompok, kegiatan yang tidak relevan selama pembelajaran berlangsung. Untuk aspek keterampilan mengemukakan pendapat dalam diskusi, yang diamati adalah penguasaan materi yang dimilki siswa. Penguasaan tersebut berhubungan dengan terampil atau tidak terampilnya siswa mengemukakan pendapat dalam diskusi.

\section{DAFTAR REFERENSI}

Asrori, M. (2008). Penelitian Tindakan Kelas. Bandung: Wacana Prima.

Robert, T. S. (2005). Online Collaborative Learning: Theory and Practice. Bandung: Alfabeta.

Shelton, R. N., \& Rawlings, H. R. (2012). Effective Evaluation of Teaching and Learning in STEM. Tucson Arizona: Research Corporation for Science Advancement.

Subiyantoro, S., \& M., U. (2018). COOPERATIVE LEARNING: LANDASAN PSIKOLOGIS, KONSEP, KARAKTERISTIK, MANFAAT DAN RESIKO PENGGUNAANNYA. Edudikara: Jurnal Pendidikan Dan Pembelajaran, 3(2), 144-153.

Suryaman. (2007). Budaya Organisasi Sekolah Berlatar Multikultural: Suatu Studi Etnografi. Universitas Negeri Malang.

Syahrin, A. (2015). PERBANDINGAN HASIL BELAJAR KETERAMPILAN MENULIS RESENSI MELALUI METODE JIGSAW DAN DISCOVERY LEARNING. . Juni, 15(13), 8.

Syahrin, A. (2017). Pembelajaran Lintas Kurikulum: Menulis Teks Eksplanasi 
Jurnal Komunikasi Pendidikan, Vol.4, No.1, 2020, pp 18-27

P-ISSN 2549-1725

www.journal.univetbantara.ac.id/index.php/komdik

Berbasis Penemuan untuk Siswa SMP. International Seminar on Language, Literature, Art, and Culture (ISLLAC). Malang.

Wiriaatmadja, R. (2006). Metode Penelitian
Tindakan Kelas . Bandung: Remaja Rosda Karya. Bandung: Remaja Rosda Karya. Yusuf, A. M. (2003). Metodologi Penelitian. Padang: Sukabina Offset. 